\title{
Penerapan Analisis Korelasi Kanonik pada Kajian Enso dalam Identifikasi Hubungan Fitur Iklim
}

\author{
Miftahuddin $^{1 *}$, Ria Andriani $^{1)}$, Ichsan Setiawan ${ }^{2)}$, dan Adi Mulsandi ${ }^{3)}$ \\ 1)Jurusan Matematika, Fakultas Matematika dan Ilmu Pengetahuan Alam, \\ Universitas Syiah Kuala, Banda Aceh 23111 \\ ${ }^{2)}$ Jurusan Ilmu Kelautan, Universitas Syiah Kuala, Banda Aceh 23111 \\ ${ }^{3)}$ Jurusan Meteorologi, AMG, Jakarta
}

Diterima 03-09-2010 Disetujui 01-10-2013

\begin{abstract}
There are several resulting arguments from the research done on climate variation in Indonesia stating that the observed affects are through various phenomena such as ENSO, monsoon, dipole mode event, and MJO. However, the magnitude of the effect varies for each region in Indonesia. This research aims to identify the relationship among the global climate features (GCFs) in the Nino3.4 $\left(5^{\circ} \mathrm{S}-5^{\circ} \mathrm{N}, 120-170^{\circ} \mathrm{W}\right)$ with the local climate features (LCFs) in the Aceh regions which represented by: $\mathrm{I}\left(2-3^{\circ} \mathrm{N}, 95-98^{\circ} \mathrm{E}\right), \mathrm{II}\left(3-4^{\circ} \mathrm{N}, 95-98^{\circ} \mathrm{E}\right), \mathrm{III}\left(4-5^{\circ} \mathrm{N}, 95-98^{\circ} \mathrm{E}\right)$, and $\mathrm{IV}\left(5-6^{\circ} \mathrm{N}, 95-98^{\circ} \mathrm{E}\right)$ using canonical correlation analysis (CCA) in the ENSO phenomena. The analysis shows that global GCFs variations have strong correlation with LCFs variations with the correlation values, $0.893,0.899,0.900$, and 0.901 , respectively. The result show that when there is a global change in any feature of GCFs, the same change also appears in each feature of LCFs. The canonical loading shows that there are original variables which have strong correlation with the first canonical global variable $\left(\mathrm{X}_{1}\right)$ with correlations $0.987,0.969,0.987$, and 0.865 , respectively, and the local wind $\left(Y_{1}\right)$ with correlations $0.974,0.952,0.979$, and 0.845 , respectively. All the other climate features have weak correlations with the first canonical variables. From the MANOVA, we can conclude that the climate features (wind, SST, SSTA, and SLP) affect climate changes in both study regions. Our results also reveal that LCFs are significantly affected in the Nino3.4 99.5\% and in I, II, III, and IV for given correlations 99.8, 99.7, 99.6, and $99.5 \%$, respectively.
\end{abstract}

Keywords: ${ }^{2}$ value, CCA, global and local climate features, loading canonic, MANOVA

\begin{abstract}
ABSTRAK
Beberapa hasil penelitian menyatakan bahwa variasi iklim di Indonesia dipengaruhi oleh berbagai fenomena seperti ENSO (El Nino Southern Oscillation), monsun, dipole mode event, dan MJO. Namun demikian besarnya pengaruh berbeda-beda untuk setiap wilayah di Indonesia. Penelitian ini bertujuan untuk mengidentifikasi hubungan antara fitur iklim global di wilayah Nino $3.4\left(5^{\circ} \mathrm{LS}-5^{\circ} \mathrm{LU}, 120-170^{\circ} \mathrm{BB}\right)$ dengan fitur iklim lokal di Provinsi Aceh yang diwakili oleh wilayah I $\left(2-3^{\circ} \mathrm{LU}\right.$, 95-98 $\left.{ }^{\circ} \mathrm{BT}\right), \mathrm{II}\left(3-4^{\circ} \mathrm{LU}, 95-98^{\circ} \mathrm{BT}\right)$, III $\left(4-5^{\circ} \mathrm{LU}, 95-98^{\circ} \mathrm{BT}\right)$, dan IV $\left(5-6^{\circ} \mathrm{LU}, 95-98^{\circ} \mathrm{BT}\right)$ menggunakan analisis korelasi kanonik dalam kaitan ENSO. Hasil analisis menunjukan bahwa variasi iklim global di Nino 3.4 memiliki hubungan kuat dengan variasi iklim lokal di wilayah Aceh dengan nilai korelasi masing-masing 0,893; 0,899; 0,900; dan 0,901. Hal ini menunjukan bahwa saat terjadi perubahan pada setiap fitur iklim global di Nino 3.4 maka perubahan juga terjadi pada setiap fitur iklim lokal. Loading kanonik menunjukkan variabel asal yaitu angin global $\left(X_{1}\right)$, memiliki korelasi terkuat dengan variabel kanonik pertama dengan masing-masing nilai korelasi 0,987; 0,969;0,987; dan 0,865, sementara variabel asal angin lokal $\left(Y_{1}\right)$ masing-masing nilai korelasi 0,974; 0,952;0,979; dan 0,845. Sedangkan fitur iklim lainnya memiliki korelasi rendah dibanding variabel kanonik pertama. Dari hasil analisis variansi multivarian (MANOVA) menyimpulkan fitur iklim (angin, SPL, anomali SPL, dan tekanan udara di atas permukaan laut) mempengaruhi perubahan fitur iklim di kedua wilayah kajian. Nilai $z^{2}$ menunjukkan bahwa fitur iklim lokal dipengaruhi oleh perubahan fitur iklim global di Nino 3.4 adalah 99,5\% dan I, II, III, IV masing-masing: 99,8; 99,7; 99,6; dan 99,5\%.
\end{abstract}

Kata Kunci: Fitur iklim global, korelasi kanonik, loading kanonik, lokal, MANOVA, nilai ${ }^{2}$

\footnotetext{
*Telp: +628156858078

Email: miftah_mft@yahoo.com
} 


\section{PENDAHULUAN}

Cuaca dan iklim di bumi ditentukan oleh jumlah dan distribusi radiasi yang diterima dari matahari (Trenberth $e t$ al. 2009). Cuaca dan iklim terdiri dari beragam fitur atau unsur, baik secara kuantitatif dan kualitatif. Pemanasan permukaan bumi oleh matahari adalah penyebab utama timbulnya variasi cuaca dan iklim baik terhadap ruang maupun waktu. Hal tersebut disebabkan adanya respon yang berbeda antar wilayah saat menerima emisi energi matahari. Perbedaan respon permukaan bumi dalam menerima panas dari matahari akan memicu variasi suhu permukaan, tekanan permukaan, dan variasi dari berbagai fitur lainnya.

Laut memiliki peranan penting dalam variasi iklim suatu wilayah, di antara parameter penting yang menentukan variasi iklim ialah suhu permukaan laut (Tjasyono \& Bayong 1999). Bentuk variasi iklim yang menjadi perhatian saat ini adalah perubahan iklim global, yakni kenaikan suhu ratarata permukaan bumi atau pemanasan global. Pemanasan global selain penyebab utama penipisan lapisan ozon sehingga menyebabkan meningkatnya suhu udara di permukaan bumi, juga menyebabkan meningkatnya suhu air laut, sehingga meningkatnya penguapan di udara, serta berubahnya pola curah hujan dan tekanan udara. Salah satu dampak perubahan iklim global akibat pemanasan global dapat terlihat jelas saat timbulnya gejala ENSO. Kaitan perubahan ini dapat dilihat juga dari perubahan amplitudo ENSO (Yeh \& Kirtman 2007). ENSO merupakan gambaran peristiwa anomali suhu permukaan laut di Pasifik, sedangkan osilasi selatan mencerminkan pola perubahan tekanan udara di Pasifik dan Hindia (Wiratmo \& Joko 1998).

Kajian terhadap prediksi ENSO melalui SST menggunakan CCA telah dilakukan oleh Branston dan Ropelewski (1992) di beberapa daerah Pasifik tropis dan samudera Hindia. Sedangkan identifikasi tipe ENSO sebagai suatu cara untuk menelusuri dampak global dari ENSO terhadap perubahan iklim (Wang 2012). CCA adalah salah satu teknik statistika multivarian untuk mengukur hubungan linier antara dua multidimensi variabel. Hubungan dalam (interrelationship) yaitu antara multi output berupa metrik dan nonmetrik dengan multi input berupa metrik maupun nonmetrik. Untuk memahami hubungan ini digunakan data iklim untuk wilayah global dan lokal. Sementara itu, perubahan iklim lokal dapat terjadi oleh berbagai akibat seperti adanya pemanasan lokal. Keterkaitan linieritas antara perubahan iklim global dan lokal adalah melatarbelakangi dilakukan kajian kuantitatif ini, terutama terhadap korelasi antara fitur iklim di kedua wilayah serta mengidentifikasi persentase hubungan fitur iklim tersebut dengan asumsi tanpa memasukkan variabel jarak antar ruang.

Perubahan Fitur Iklim. Perubahan iklim dapat dibedakan berdasarkan ruang (wilayah), yaitu perubahan iklim lokal dan global. Berdasarkan waktu, iklim dapat berubah dalam bentuk siklus, seperti harian, bulanan, musiman, dan tahunan. Perubahan tersebut dapat direpresentasikan sebagai kanonik deret waktu dan pola kanonik, sehingga ada korespondensi korelasi (kanonik). Perubahan iklim adalah kondisi cuaca yang berlaku di daerah secara umum (dalam ruang yang luas) dan dalam jangka panjang (periode waktu yang lama). Kecenderungan perubahan naik atau turun suatu fitur dapat disebabkan oleh perubahan iklim global seperti oleh meningkatnya konsentrasi gas di atmosfer. Kondisi ini dapat menyebabkan mencairnya es di kutub, permukaan laut naik, dampak pada bidang pertanian, ekonomi (Chen et al. 2000), meningkatnya resiko kebakaran hutan, dan berbagai bidang kehidupan lainnya seperti berubahnya lingkungan sekitar, antara lain semakin meningkatnya total temperatur dan berubahnya kondisi cuaca pada lingkungan lokal.

Fitur cuaca dan iklim utama antara lain suhu udara, kelembaban udara, curah hujan, tekanan udara, angin, dan durasi sinar matahari. Faktor yang mempengaruhi fitur iklim sehingga membedakan iklim di suatu tempat dengan iklim di tempat lain disebut kendali iklim. Matahari adalah kendali iklim yang dapat menimbulkan gerak udara dan arus laut (Tjasyono \& Boyong 1999). Curah hujan berkaitan dengan konvergensi angin (sirkulasi Walker) terjadi di Indonesia dan lokasi kolam panas tersebut. Angin yang konvergen memberikan stress ke arah timur di atas Samudera Pasifik dan ke arah barat di atas Samudera Hindia. Komponen sirkulasi ini menyebabkan menurunnya curah hujan di bagian timur Samudera Pasifik dan bagian barat Samudera Hindia (Bannu 2003). Suhu Permukaan Laut (SPL) sangat bergantung pada jumlah panas yang diterima dari matahari. Daerah yang paling banyak menerima panas dari matahari adalah daerah pada lintang 0 (daerah ekuator). Pengaruh anomali Suhu Permukaan Laut (ASPL) terlihat dalam dua bentuk, yaitu peningkatan atau penurunan curah hujan di Indonesia. Landman dan Mason (1999) mengkaji hubungan ENSO dan curah hujan menggunakan CCA. El-Nino adalah gejala alam global yang terjadi akibat anomali hasil interaksi antara kondisi permukaan samudera dan atmosfer di kawasan Pasifik sekitar ekuator. Di Indonesia pengaruh El-Nino dapat 
menyebabkan curah hujan di bawah normal atau menyebabkan kemarau yang lebih panjang dari biasanya, sebaliknya dengan La-Nina dapat menyebabkan curah hujan di atas normal atau menyebabkan musim hujan yang lebih panjang dari biasanya. Pada Gambar 1 diperlihatkan nilai korelasi spasial antara kejadian El-Nino dengan fitur curah hujan di wilayah Indonesia termasuk Provinsi Aceh untuk tahun 1963, 1972, 1982, dan 1997 di stasiun Lhokseumawe, Banda Aceh, dan Meulaboh.

Interpretasi Analisis Korelasi Kanonik. Analisis korelasi kanonik merupakan teknik statistika multivarian untuk menyelidiki hubungan di antara dua kumpulan variabel, yaitu kumpulan variabel independen dan variabel dependen (Dillon et al. 1984; Raykov \& Marcoulides 2008). Asumsi linieritas terdapat pada dua aspek hasil korelasi kanonik yaitu, koefisien korelasi di antara dua variabel asal didasarkan pada hubungan linier dan korelasi kanonik memiliki hubungan linier di antara variabel kanonik (Hair $e t$ al. 1998; Timm \& Neil, 2002, Everitt \& Brian 2005; Stevans \& James 2009; Everitt et al. 2011). Misalkan $m$ adalah jumlah variabel independen dan $p$ jumlah variabel dependen, dan asumsi bahwa $m \geq p$. Misalkan $X^{\prime}=\left(X_{1}, X_{2}, \ldots, X_{m}\right)$, dimensi $m$ adalah vektor variabel independen dan $Y^{\prime}=\left(Y_{1}, Y_{2}, \ldots, Y_{p}\right)$, dimensi $p$ adalah vektor variabel dependen. Misalkan ${ }_{x}$ dan y notasi setiap vektor rataan yang berhubungan dengan kumpulan variabel $X$ dan $Y$,

$\boldsymbol{\Sigma}_{x x}=E\left\{\left(\mathbf{X}-\boldsymbol{\mu}_{x}\right)\left(\mathbf{X}-\boldsymbol{\mu}_{x}\right)^{\prime}\right\}, \quad \boldsymbol{\Sigma}_{y y}=E\left\{\left(\mathbf{Y}-\boldsymbol{\mu}_{y}\right)\left(\mathbf{Y}-\boldsymbol{\mu}_{y}\right)\right\}$,

$\boldsymbol{\Sigma}_{x y}=E\left\{\left(\mathbf{X}-\boldsymbol{\mu}_{x}\right)\left(\mathbf{Y}-\boldsymbol{\mu}_{y}\right)\right\}$

di mana, $\boldsymbol{\Sigma}_{x x}$ dan $\boldsymbol{\Sigma}_{y y}$ adalah dalam matriks varians kovarians, $\boldsymbol{\Sigma}_{x y}\left(\boldsymbol{\Sigma}_{y x}\right)$ adalah antar matriks kovarians. Untuk menemukan kombinasi linier dari $m$ variabel independen dan $p$ variabel dependen yang memiliki korelasi terbesar seperti

$$
\begin{aligned}
X^{*} & =\mathbf{a}^{\prime} \mathbf{X}=a_{1} X_{1}+a_{2} X_{2}+\ldots+a_{m} X_{m} \\
Y^{*} & =\mathbf{b}^{\prime} \mathbf{Y}=b_{1} Y_{1}+b_{2} Y_{2}+\ldots+b_{p} Y_{p}
\end{aligned}
$$

maka korelasi fungsi a dan b untuk $X^{*}$ dan $Y^{*}$ adalah

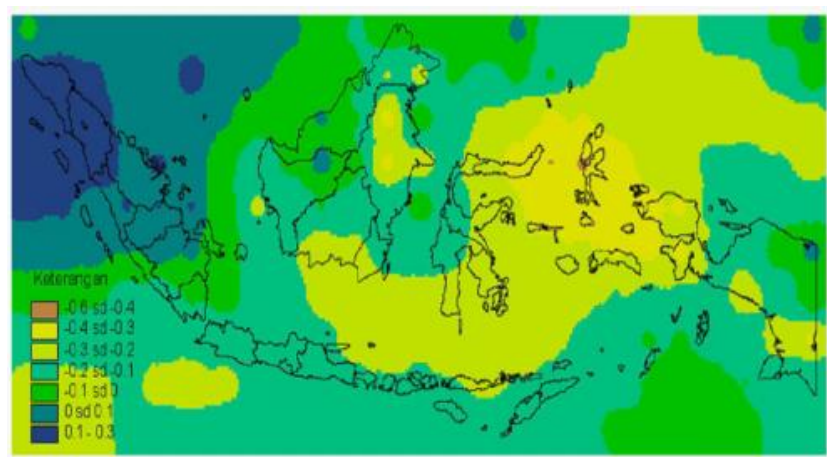

Gambar 1 Nilai korelasi spasial antara kejadian El-Nino dengan curah hujan wilayah Indonesia (sumber: Harijono 2008)

$$
\rho(\mathbf{a}, \mathbf{b})=\frac{\mathbf{a} \boldsymbol{\Sigma}_{x y} \mathbf{b}}{\left\{\left(\mathbf{a} \boldsymbol{\Sigma}_{x x} \mathbf{a}\right)\left(\mathbf{b}^{\prime} \boldsymbol{\Sigma}_{y y} \mathbf{b}\right)\right\}^{1 / 2}}
$$

di mana, $\rho$ adalah koefisien korelasi kanonik. Bila nilai a dan b maksimum $\rho(\mathbf{a}, \mathbf{b})$ solusi $\max _{\mathbf{a}, \mathbf{b}} \mathbf{a} \boldsymbol{\Sigma}_{x y} \mathbf{b}$ berlaku jika $\mathbf{a}^{\prime} \sum_{x x} \mathbf{a}=\mathbf{b}^{\prime} \sum_{y y} \mathbf{b}=1$ karena (2) tidak bergantung pada skala a dan b (Mardia et al. 1979; Hardon et al. 2003). Anderson (1958) menunjukkan bahwa persamaan kanonik dapat dihasilkan dari

$\left(\boldsymbol{\Sigma}_{x x}^{-1} \boldsymbol{\Sigma}_{x y} \boldsymbol{\Sigma}_{y y}^{-1} \boldsymbol{\Sigma}_{y x}-\lambda \mathbf{I}\right) \mathbf{a}=0$

$\left(\boldsymbol{\Sigma}_{y y}^{-1} \boldsymbol{\Sigma}_{y x} \boldsymbol{\Sigma}_{x x}^{-1} \boldsymbol{\Sigma}_{x y}-\lambda \mathbf{I}\right) \mathbf{b}=0$

di mana, $\boldsymbol{\Sigma}_{x x}, \boldsymbol{\Sigma}_{y y}, \boldsymbol{\Sigma}_{x y}$, dan $\boldsymbol{\Sigma}_{v x}$ telah ditentukan sebelumnya, I matriks identitas, dan $\lambda$ nilai eigen terbesar dari persamaan karakteristik. Nilai eigen terbesar dari matriks $\boldsymbol{\Sigma}_{x x}^{-1} \boldsymbol{\Sigma}_{x y} \boldsymbol{\Sigma}_{y y}^{-1} \boldsymbol{\Sigma}_{y x}$ atau $\boldsymbol{\Sigma}_{y y}^{-1} \boldsymbol{\Sigma}_{y x} \boldsymbol{\Sigma}_{x x}^{-1} \boldsymbol{\Sigma}_{x y}$ adalah koefisien kuadrat korelasi kanonik. Terdapat dua kumpulan vektor eigen, yaitu untuk $\boldsymbol{\Sigma}_{x x}^{-1} \boldsymbol{\Sigma}_{x y} \boldsymbol{\Sigma}_{y y}^{-1} \boldsymbol{\Sigma}_{y x}$ dan $\boldsymbol{\Sigma}_{y y}^{-1} \boldsymbol{\Sigma}_{y x} \boldsymbol{\Sigma}_{x x}^{-1} \boldsymbol{\Sigma}_{x y}$ (Dillon et al. 1984)

Analisis korelasi kanonik sampel dari $n$ respon pada dimensi $(m+p)$ variabel $Z=(X, Y)$. Matriks varians-kovarians dapat dibangun dari matriks data di atas. Matriks varianskovarians sampel (Johnson \& Wichern 2007) dapat disusun menggunakan persamaan

$\mathbf{S}_{x y}=\frac{1}{n-1} \sum_{i=1}^{n}\left(\mathbf{x}_{t x}-\overline{\mathbf{x}}_{x}\right)\left(\mathbf{y}_{i y}-\overline{\mathbf{y}}_{y}\right), x=1,2, \ldots, m$ dan $y=1,2, \ldots, p$

Dua matriks hasil dalam analisis adalah $\mathbf{S}_{x x}^{-1} \mathbf{S}_{x y} \mathbf{S}_{y y}^{-1} \mathbf{S}_{y x}$ dan $\mathbf{S}_{y y}^{-1} \mathbf{S}_{y x} \mathbf{S}_{x x}^{-1} \mathbf{S}_{x y}$ di mana, $\mathbf{S}_{y y}^{-1} \mathbf{S}_{y x} \mathbf{S}_{x x}^{-1} \mathbf{S}_{x y}$ dan $\mathbf{S}_{y x}$ adalah sampel sebagai dasar penduga terhadap $\boldsymbol{\Sigma}_{x x}, \boldsymbol{\Sigma}_{y y}, \boldsymbol{\Sigma}_{x y}$ dan $\boldsymbol{\Sigma}_{y x}$ (Dillon et al. 1984). Dalam beberapa kasus variabel $X$ dan $Y$ dalam susunan matriks data dibakukan sehingga matriks varians-kovarians adalah matriks korelasi. Matriks korelasi sampel diperoleh dari:

$\mathbf{R}_{x y}=\mathbf{D}_{x x}^{-1 / 2} \mathbf{S}_{x y} \mathbf{D}_{y y}^{-1 / 2}, x=1,2, \ldots, m$ dan $y=1,2, \ldots, p$

dimana: $\mathbf{D}_{x x}^{-1 / 2}$ dan $\mathbf{D}_{y y}^{-1 / 2}$ masing-masing matriks diagonal dengan unsur diagonal $\frac{1}{\sqrt{S_{x x}}}$; dan $\frac{1}{\sqrt{S_{y y}}}$, (Johnson \& Wichern 2007). Dua matriks hasil analisis menjadi $\mathbf{R}_{x x}^{-1} \mathbf{R}_{x y} \mathbf{R}_{y y}^{-1} \mathbf{R}_{y x}, \mathbf{R}_{y y}^{-1} \mathbf{R}_{y x} \mathbf{R}_{x x}^{-1} \mathbf{R}_{x y}$ di mana, $\mathbf{R}_{x x}$ matriks korelasi dibentuk dari variabel $X, \mathbf{R}_{y y}$ matriks korelasi dibentuk dari variabel $Y$, dan $\mathbf{R}_{x y}\left(\mathbf{R}_{y x}\right)$ matriks korelasi yang dibentuk dari kedua variabel $X$ dan $Y$. Sampel sebagai dasar penduga terhadap bobot kanonik dinotasikan $\hat{\mathbf{a}} \operatorname{dan} \hat{\mathbf{b}}$ (Dillon et al. 1984).

Vektor loading kanonik yang berhubungan dengan variabel kanonik ke-j dapat diperoleh dari perkalian vektor bobot kanonik dan matriks korelasi

$$
\mathbf{r}_{x^{*} x}^{(j)}=\mathbf{R}_{x x} \hat{\mathbf{a}}^{(j)} \quad \mathbf{r}_{y^{*} y}^{(j)}=\mathbf{R}_{y y} \hat{\mathbf{b}}^{(j)}
$$


di mana, $\mathbf{R}_{x x}$ dan $\mathbf{R}_{y y}$ matriks korelasi dalam kumpulan, $\hat{\mathbf{a}}^{(/)}$ dan $\hat{\mathbf{b}}^{(j)}$ adalah vektor bobot kanonik dari kumpulan variabel $X$ dan $Y$ pada variabel kanonik ke-j. Bartlett (1951) menguraikan prosedur untuk uji signifikansi statistik untuk analisis korelasi kanonik ketika ukuran sampel besar. Untuk hipotesis nol bahwa variabel dependen $p$ tidak berkorelasi dengan variabel independen $m$,

$$
\mathrm{H}_{0}: \Sigma_{y x}=0 \quad \mathrm{H}_{1}: \Sigma_{y x} \neq 0
$$

Bartlett mendefinisikan $\Lambda=\prod_{j=1}^{M}\left(1-\hat{\lambda}_{(j)}\right)$ di mana, $\Lambda$ variabel lambda Wilks' dan $M=\min (m, p)$. Bartlett menggunakan pendekatan chi-square $\left(\chi^{2}\right)$ untuk distribusi $\Lambda$ adalah

$$
X^{2}=-\left[(n-1)-\frac{1}{2}(m+p+1)\right] \ln \Lambda
$$

Hipotesis (6) ditolak jika $X^{2}>\chi_{m p}^{2}(\alpha)$ (Dillon et al. 1984).

Model MANOVA untuk perbandingan vektor nilai tengah $g$ populasi adalah

$$
\mathbf{X}_{l j}=\boldsymbol{\mu}+\boldsymbol{\tau}_{l}+\mathbf{e}_{l j}, j=1,2, \ldots . ., n_{l} \text { dan } l=1,2, \ldots . ., g
$$
di mana, $\mathbf{e}_{l j}$ variabel bebas $N_{p}(\mathbf{0}, \mathbf{\Sigma})$. Vektor parameter $\boldsymbol{\mu}$ nilai rata-rata umum dan $\boldsymbol{\tau}_{l}$ mencerminkan pengaruh perlakuan ke- $l$ dengan $\sum_{l=1}^{g} n_{l} \boldsymbol{\tau}_{l}=0$ (Rencher \& Alvian 2002; Hardle \& Simar 2012).

Menurut Gaspersz \& Vincent (1992), asumsi MANOVA adalah nilai galat bersifat bebas dan berdistribusi multinormal dengan vektor nilai rata-rata nol dan matriks kovarians $\boldsymbol{\Sigma}$. Berdasarkan model (8) setiap komponen dari vektor pengamatan $\mathbf{X}_{l j}$ memenuhi model ANOVA. Galat untuk komponen $\mathbf{X}_{l j}$ berkorelasi, tetapi matriks kovarians $\boldsymbol{\Sigma}$ adalah sama untuk semua populasi. Vektor pengamatan dapat didekomposisi sebagaimana dinyatakan (Johnson et al. 2007).

$$
\mathbf{x}_{l j}=\overline{\mathbf{x}}+\left(\overline{\mathbf{x}}_{l}-\overline{\mathbf{x}}\right)+\left(\mathbf{x}_{l j}-\overline{\mathbf{x}}_{l}\right)
$$

Menurut Gaspersz (1992) pada analisis varians univariat, pengujian hipotesis pengaruh hubungan $\mathrm{H}_{0}: \boldsymbol{\tau}_{1}=\boldsymbol{\tau}_{2}=\cdots=\boldsymbol{\tau}_{g}=0$ dan $\mathrm{H}_{1}$ : paling sedikit ada satu $(l=1,2, \ldots, g)$ diuji dengan membandingkan besarnya jumlah kuadrat dan hasil kali galat relatif dan total (terkoreksi). Uji hipotesis dapat menggunakan uji Lambda Wilks' $\left(\Lambda^{*}\right)$,

$$
\Lambda^{*}=\frac{|\mathbf{W}|}{|\mathbf{B}+\mathbf{W}|}=\frac{\left|\sum_{l=1}^{g} \sum_{j=1}^{n_{l}}\left(\mathbf{x}_{l j}-\overline{\mathbf{x}}_{l}\right)\left(\mathbf{x}_{l j}-\overline{\mathbf{x}}_{l}\right)^{\prime}\right|}{\left|\sum_{l=1}^{g} \sum_{j=1}^{n_{l}}\left(\mathbf{x}_{l j}-\overline{\mathbf{x}}\right)\left(\mathbf{x}_{l j}-\overline{\mathbf{x}}\right)^{\prime}\right|}
$$

di mana, $|\mathbf{W}|$ adalah determinan dari matriks galat dan $|\mathbf{B}+\mathbf{W}|$ determinan dari matriks total (terkoreksi dengan nilai rata-rata). Bartlett (1951) menunjukkan bahwa apabila $\sum n_{l}=n$ besar, maka

$$
-\left(n-1-\frac{(p+g)}{2}\right) \ln \Lambda^{*}=-\left(n-1-\frac{(p+g)}{2}\right) \ln \left(\frac{|\mathbf{W}|}{|\mathbf{B}+\mathbf{W}|}\right)
$$

dapat didekati sebaran chi-square dengan derajat bebas $p$ ( $g$ 1). Sehingga, $\mathrm{H}_{0}$ ditolak pada taraf $\alpha$ apabila,

$-\left(n-1-\frac{(p+g)}{2}\right) \ln \Lambda^{*}>\chi_{p(g-1)}^{2}(\alpha)$

di mana, $\chi_{p(g-1)}^{2}(\alpha)$ adalah persentil ke-100 $\alpha$ dari distribusi chi-square dengan derajat bebas $p(g-1)$ (Supranto 2004, Johnson \& Wichern 2007). Eta kuadrat $\left(\eta^{2}\right)$ merupakan ukuran kuatnya pengaruh $X$ (variabel bebas, nonmetrik sebagai faktor) pada variabel respon $Y$ sebagai variabel metrik $\left(0 \leq\left(\eta^{2}\right) \leq 1\right)$. Kekuatan pengaruh hubungan variabel $X$ terhadap $Y$ diukur sebagai rasio dari $S S_{x} / S S_{y}$ di mana, $S S_{x}$ jumlah varians perlakuan $S S_{y}$ dan jumlah varians total.

\section{BAHAN DAN METODE}

Data yang digunakan adalah data sekunder yang diperoleh dari Satelit National Oceanic and Atmospheric Administration (NOAA)/National Centers for Environmental Prediction (NCEP) selama Januari 1951 sampai dengan Desember 2007. Data dibagi dalam dua bagian yaitu global adalah data dari wilayah Nino $3.4\left(5^{\circ} \mathrm{LS}-5^{\circ} \mathrm{LU}, 120\right.$ $\left.170^{\circ} \mathrm{BB}\right)$ (Gambar 2).

Sedangkan lokal adalah data wilayah Provinsi Aceh (2-6 ${ }^{\circ} \mathrm{LU}, 95-98^{\circ} \mathrm{BT}$ ) yang dibagi menjadi empat wilayah kajian grid yaitu, wilayah I (2-3 $\left.{ }^{\circ} \mathrm{LU}, 95-98^{\circ} \mathrm{BT}\right)$, wilayah II (3-4 $\left.4^{\circ} \mathrm{LU}, 95-98^{\circ} \mathrm{BT}\right)$, wilayah III (4-5 $\left.{ }^{\circ} \mathrm{LU}, 95-98^{\circ} \mathrm{BT}\right)$, dan wilayah IV (5-6 $\left.{ }^{\circ} \mathrm{LU}, 95-98^{\circ} \mathrm{BT}\right)$ yang juga diperoleh dari satelit NOAA dengan rentang waktu yang sama. Variabel data yang digunakan sebagai fitur yang dapat mempengaruhi perubahan iklim global dan lokal adalah angin (meter/detik), suhu permukaan laut $\left({ }^{\circ} \mathrm{C}\right)$, anomali suhu permukaan laut $\left({ }^{\circ} \mathrm{C}\right)$, dan tekanan udara di atas permukaan laut (milibar).

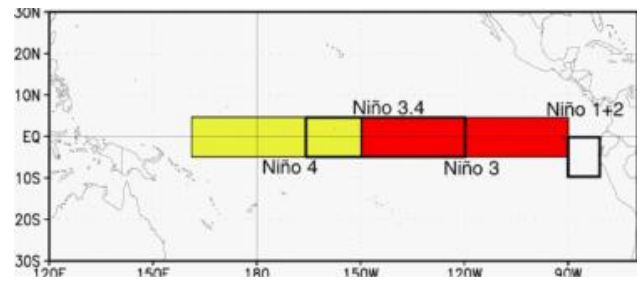

Gambar 2 Posisi wilayah Nino di Samudera Pasifik, sumbu horizontal (longitude) dan sumbu vertikal (latitude), warna kuning merepresentasikan wilayah Nino 4, warna merah untuk Nino 3, warna putih untuk Nino $1+2$ dan persegi panjang antara warna kuning dan merah untuk Nino3.4 (Sumber: http://www.cpc.ncep.noaa.gov) 
Prosedur yang dilakukan adalah mengidentifikasi data, menyusun matriks korelasi $\left(\mathbf{R}_{x x}, \mathbf{R}_{y y}, \mathbf{R}_{x y}\left(\mathbf{R}_{y x}\right)\right)$. Matriks korelasi diperoleh dari persamaan (4). Kemudian menghitung nilai eigen dan vektor eigen. Berdasarkan matriks korelasi dapat diperoleh nilai eigen melalui perhitungan $\left|\mathbf{R}_{x x}^{-1} \mathbf{R}_{x y} \mathbf{R}_{y y}^{-1} \mathbf{R}_{y x}-\hat{\lambda} \mathbf{I}\right|=0$ atau $\left|\mathbf{R}_{y y}^{-1} \mathbf{R}_{y x} \mathbf{R}_{x x}^{-1} \mathbf{R}_{y y}-\hat{\lambda} \mathbf{I}\right|=0$ sedangkan vektor eigen dapat diperoleh melalui modifikasi persamaan (3) dan (4). Selanjutnya, menghitung koefisien korelasi kanonik $\left(\hat{\rho}_{j}\right)$. Nilai eigen terbesar dari matriks korelasi merupakan koefisien kuadrat korelasi kanonik dan menentukan bobot kanonik $\left(\hat{\mathbf{a}}^{(/)}, \hat{\mathbf{b}}^{(j)}\right)$. Vektor eigen dari matriks korelasi merupakan bobot kanonik. Tahapan berikutnya adalah menentukan loading kanonik $\left(\mathbf{r}_{x^{*} x}^{(j)}, \mathbf{r}_{y^{y} y}^{(j)}\right)$ yang diperoleh dari hasil perkalian matriks korelasi dan bobot kanonik serta menunjukkan korelasi diantara variabel asal dengan variabel kanonik. Melakukan pengujian statistik secara multivarian terhadap korelasi kanonik serta menyimpulkan hasil perhitungan dan pengujian statistik. Pada proses analisis korelasi kanonik dibagi dalam dua bagian yaitu, perhitungan korelasi kanonik hingga tahap pengujian statistik dan perhitungan loading kanonik untuk mengetahui fitur iklim yang paling berperan dalam perubahan iklim.

Beberapa tahapan dilakukan seperti mengidentifikasi data di mana variabel respon adalah perubahan iklim di wilayah global $\left(P_{1}\right)$ dan perubahan iklim di wilayah lokal $\left(P_{2}\right)$. Fitur iklim $(G)$ dinotasikan sebagai perlakuan yang terbagi dalam 4 kelompok yaitu angin $\left(G_{1}\right)$, suhu permukaan laut $\left(G_{2}\right)$, anomali suhu permukaan laut $\left(G_{3}\right)$, dan tekanan udara di atas permukaan laut $\left(G_{4}\right)$. Selanjutnya melakukan perhitungan jumlah varians untuk perlakuan $\mathbf{B}$, galat $\mathbf{W}$, total $(\mathbf{B}+\mathbf{W})$, melakukan pengujian statistik secara multivarian dan mengukur besar pengaruh fitur iklim terhadap perubahan iklim di wilayah global dan lokal, serta pengujian statistik dan membuat kesimpulan.

\section{HASIL DAN PEMBAHASAN}

Diketahui dari hasil riset sebelumnya (Harijono \& Sriwono 2008) bahwa wilayah Provinsi Aceh memiliki korelasi antara peristiwa $\mathrm{El}$-Nino dengan curah hujan adalah positif dengan nilai korelasi kecil untuk data dari kurun waktu empat tahun secara acak. Hasil analisis korelasi ini berbeda signifikan, bila untuk fitur iklim lokal yang digunakan bertambah jumlahnya, dan periode waktu yang digunakan lebih lama, serta rentang waktunya tidak secara acak (atau sekuensial) seperti dalam kajian ini. Dari hasil analisis korelasi kanonik diperoleh beberapa tahapan sebagai berikut: a. Konstruksi matriks korelasi variabel independen (perubahan iklim global/X)

$$
\left[\begin{array}{rrrr}
1.000 & -.048 & -.121 & .102 \\
-.048 & 1.000 & .883 & -.342 \\
-.121 & .883 & 1.000 & -.358 \\
.102 & -.342 & -.358 & 1.000
\end{array}\right]
$$

Nilai korelasi antara fitur perubahan iklim di wilayah Nino 3.4 menunjukkan hubungan linier seperti suhu permukaan laut (SPL) $\left(X_{2}\right)$ dan anomali suhu permukaan laut (ASPL) $\left(X_{3}\right)$ dengan korelasi 0,883 (hubungan linier positif dengan korelasi kuat sebesar 88,3\%), suhu permukaan laut $\left(X_{2}\right)$ dan tekanan udara di atas permukaan laut $\left(X_{4}\right)$ dengan korelasi $-0,342$ (hubungan linier negatif dengan korelasi lemah sebesar 34,2\%), ASPL $\left(X_{3}\right)$ dan tekanan udara di atas permukaan laut $\left(X_{4}\right)$ dengan korelasi-0,358. Ketiga variabel ini memiliki hubungan linier yang rendah dengan angin $\left(X_{1}\right)$. Secara fisis, korelasi di antara SPL, ASPL, dan tekanan udara di atas permukaan laut menjelaskan bahwa anomali suhu dapat mempengaruhi penurunan (tanda negatif) atau peningkatan (tanda positif) suhu permukaan laut dari kondisi normal. Perubahan SPL ini dapat mengakibatkan terjadinya perubahan tekanan udara di atas permukaan laut di wilayah Nino 3.4

b. Konstruksi matriks korelasi variabel dependen (perubahan iklim lokal/Y)

$$
\begin{gathered}
\text { wilayah I } \\
{\left[\begin{array}{rrrr}
1.000 & .023 & -.149 & -.090 \\
.023 & 1.000 & .458 & .111 \\
-.149 & .310 & 1.000 & .130 \\
-.090 & .111 & .130 & 1.000
\end{array}\right] \quad\left[\begin{array}{rrrr}
1.000 & .025 & -.142 & -.092 \\
.025 & 1.000 & .446 & .100 \\
-.142 & .446 & 1.000 & .127 \\
-.092 & .100 & .127 & 1.000
\end{array}\right]} \\
\\
\text { wilayah III } \\
{\left[\begin{array}{rrrr}
1.000 & .021 & -.137 & -.094 \\
.021 & 1.000 & .428 & .101 \\
-.137 & .428 & 1.000 & .128 \\
-.094 & .102 & .128 & 1.000
\end{array}\right] \quad\left[\begin{array}{rrrr}
1.000 & .029 & -.132 & -.093 \\
.029 & 1.000 & .415 & .079 \\
-.132 & .415 & 1.000 & .126 \\
-.093 & -.079 & .126 & 1.000
\end{array}\right]}
\end{gathered}
$$

Nilai korelasi antara fitur perubahan iklim di wilayah I, II, III, dan IV menunjukkan hubungan linier seperti SPL $\left(Y_{2}\right)$ dan ASPL $\left(Y_{3}\right)$ wilayah I dengan korelasi 0,458, SPL $\left(Y_{2}\right)$ dan $\operatorname{ASPL}\left(Y_{3}\right)$ wilayah II dengan nilai korelasi 0,446, SPL $\left(Y_{2}\right)$ dan ASPL $\left(Y_{3}\right)$ wilayah III dengan korelasi 0,428, SPL $\left(Y_{2}\right)$ dan ASPL $\left(Y_{3}\right)$ wilayah IV dengan korelasi 0,415 . Kedua variabel ini memiliki hubungan linier yang rendah dengan angin $\left(Y_{1}\right)$ dan tekanan udara di atas permukaan laut $\left(Y_{4}\right)$. c. Matriks korelasi silang variabel independen dan dependen $(X Y)$ 
wilayah I

$\left[\begin{array}{rrrr}.887 & .104 & -.077 & -.070 \\ -.078 & .501 & .252 & .399 \\ -.129 & .185 & .300 & .442 \\ .053 & .128 & .138 & .138\end{array}\right] \quad\left[\begin{array}{rrrr}.893 & .097 & -.078 & -.072 \\ -.075 & .516 & .252 & .402 \\ -.128 & .186 & .300 & .442 \\ .053 & .120 & .138 & .141\end{array}\right]$

wilayah III

$$
\left[\begin{array}{rrrr}
.896 & .083 & -.078 & -.071 \\
-.075 & .527 & .252 & .408 \\
-.130 & .195 & .301 & .447 \\
.054 & .096 & .139 & .146
\end{array}\right] \quad\left[\begin{array}{rrrr}
.896 & .077 & -.078 & -.065 \\
-.071 & .528 & .253 & .413 \\
-.128 & .175 & .301 & .452 \\
.049 & .061 & .139 & .144
\end{array}\right]
$$

Nilai korelasi antara fitur iklim di wilayah Nino 3.4 dan fitur iklim di wilayah I menunjukkan hubungan linier seperti angin global $\left(X_{1}\right)$ dan lokal $\left(Y_{1}\right)$ dengan korelasi terbesar 0,887, SPL global $\left(X_{2}\right)$ dan lokal $\left(Y_{2}\right)$ dengan korelasi 0,501, SPL global $\left(X_{2}\right)$ dan tekanan udara di atas permukaan laut lokal $\left(Y_{4}\right)$ dengan korelasi 0,399, ASPL global $\left(X_{3}\right)$ dan tekanan udara di atas permukaan laut lokal $\left(Y_{4}\right)$ dengan korelasi 0,442.

Untuk wilayah Nino 3.4 dan wilayah II menunjukkan hubungan linier seperti angin global $\left(X_{1}\right)$ dan lokal $\left(Y_{1}\right)$ dengan korelasi 0,893, SPL global $\left(X_{2}\right)$ dan lokal $\left(Y_{2}\right)$ dengan korelasi 0,516, SPL global $\left(X_{2}\right)$ dan tekanan udara di atas permukaan laut lokal $\left(Y_{4}\right)$ dengan korelasi 0,402, ASPL global $\left(X_{3}\right)$ dan tekanan udara di atas permukaan laut lokal $\left(Y_{4}\right)$ dengan korelasi 0,442. Sedangkan wilayah Nino 3.4 dan wilayah III menunjukkan hubungan linier : angin global $\left(X_{1}\right)$ dan lokal $\left(Y_{1}\right)$ dengan korelasi 0,896, SPL global $\left(X_{2}\right)$ dan lokal $\left(Y_{2}\right)$ dengan korelasi 0,527, SPL global $\left(X_{2}\right)$ dan tekanan udara di atas permukaan laut lokal $\left(Y_{4}\right)$ dengan korelasi 0,408, ASPL global $\left(X_{3}\right)$ dan tekanan udara di atas permukaan laut lokal $\left(Y_{4}\right)$ dengan korelasi 0,447.

Selanjutnya nilai korelasi antara fitur iklim di wilayah Nino 3.4 dan fitur iklim di wilayah IV menunjukkan hubungan linier seperti angin global $\left(X_{1}\right)$ dan lokal $\left(Y_{1}\right)$ dengan korelasi
0,896, SPL global $\left(X_{2}\right)$ dan lokal $\left(Y_{2}\right)$ dengan korelasi 0,528, SPL global $\left(X_{2}\right)$ dan tekanan udara di atas permukaan laut lokal $\left(Y_{4}\right)$ dengan korelasi 0,413, ASPL global $\left(X_{3}\right)$ dan tekanan udara di atas permukaan laut lokal $\left(Y_{4}\right)$ dengan korelasi 0,452. Secara fisis, korelasi diantara ketiga variabel tersebut menjelaskan bahwa anomali suhu mengakibatkan penurunan (korelasi negatif) atau peningkatan (korelasi positif) SPL dari kondisi normal. Perubahan SPL diikuti dengan perubahan tekanan udara di atas permukaan laut. Kondisi ini dapat mempengaruhi pola arah angin yang akan terjadi.

Pengambilan nilai korelasi kanonik dilakukan pada variabel kanonik pertama karena variabel kanonik pertama dapat menjelaskan korelasi kuat di antara fitur iklim di Nino 3.4 dan di wilayah lokal. Berdasarkan Tabel 1 hubungan fitur iklim selama tahun 1951-2007 terjadi korelasi di antara fitur iklim global dan lokal wilayah I $(0,893)$, II $(0,899)$, III $(0,900)$, dan IV $(0,901)$ secara positif. Nilai korelasi positif di antara fitur iklim global dan lokal menunjukkan bahwa saat terjadi perubahan pada setiap fitur iklim di wilayah Nino 3.4 maka perubahan juga terjadi pada setiap fitur iklim di wilayah lokal dalam hubungan linier positif.

Selanjutnya melalui Tabel 2 pengujian korelasi kanonik menggunakan uji Wilks:

$\mathrm{H}_{0}: \hat{\rho}_{1}=\hat{\rho}_{2}=\hat{\rho}_{3}=\hat{\rho}_{4}=0$ (tidak ada korelasi kanonik yang signifikan).

$\mathrm{H}_{1}$ : paling sedikit ada satu $\hat{\rho}_{j} \neq 0(j=1,2,3,4)$

Berdasarkan Tabel 3 untuk chi-square diperoleh $\chi_{(\alpha, m p)}^{2}=\chi_{(0.05,16)}^{2}=26.30$. Bila hasil perhitungan nilai $X^{2}$ untuk perubahan fitur global (Nino 3.4) dan fitur lokal dibandingkan dengan $\chi_{(\alpha, m p)}^{2}$ diperoleh $X^{2}>\chi_{(\alpha, m p)}^{2}$ maka kesimpulannya menolak $\mathrm{H}_{0}$. Hasil yang sama juga terlihat pada nilai signifikansi di bawah 0.05 .

Tabel 1 Koefisien korelasi kanonik wilayah Nino 3.4 dan Provinsi Aceh

\begin{tabular}{cccc}
\hline \multirow{2}{*}{ Akar ke } & \multicolumn{2}{c}{ Koefisien korelasi kanonik $(\hat{\rho})$} \\
\cline { 2 - 4 } & Nino 3.4 dan I & Nino 3.4 dan II & Nino 3.4 dan III \\
\hline 1 & 0,893 & 0,899 & 0,900 \\
3 & 0,839 & 0,866 & 0,867 \\
4 & 0,619 & 0,621 & 0,628 \\
0,003 & 0,892 \\
\hline
\end{tabular}

Tabel 2 Uji signifikansi multivariat terhadap korelasi kanonik di Nino 3.4 dan Provinsi Aceh

\begin{tabular}{|c|c|c|c|c|}
\hline \multirow{2}{*}{ Nilai } & \multicolumn{4}{|c|}{ Wilayah Nino 3.4} \\
\hline & Wilayah I & Wilayah II & Wilayah III & Wilayah IV \\
\hline Lambda Wilks' & 0,03670 & 0,02941 & 0,02869 & 0,02276 \\
\hline
\end{tabular}

Tabel 3 Nilai $X^{2}$ untuk masing-masing wilayah kajian

\begin{tabular}{llll}
\hline Perubahan Iklim & \multicolumn{2}{c}{ Lokal } \\
\hline Wilayah Nino 3.4 & wilayah I & wilayah II & wilayah III \\
\hline Nilai $X^{2}$ & 2242,429 & 2392,676 & 2409,496 \\
\hline
\end{tabular}


Tabel 4 menunjukkan bobot kanonik yang telah dibakukan untuk fitur global pada kajian wilayah I, II, dan III dengan kontribusi terbesar sampai terkecil: angin $\left(X_{1}\right)$, suhu permukaan laut $\left(X_{2}\right)$, ASPL $\left(X_{3}\right)$, dan tekanan udara di atas permukaan laut $\left(X_{4}\right)$. Sedangkan bobot kanonik yang telah dibakukan untuk fitur global pada kajian wilayah IV dengan kontribusi terbesar sampai terkecil adalah SPL $\left(X_{2}\right)$, ASPL $\left(X_{3}\right)$, angin $\left(X_{1}\right)$, dan tekanan udara di atas permukaan laut $\left(X_{4}\right)$.

Tabel 5 menunjukkan bobot kanonik yang telah dibakukan untuk fitur lokal dengan kontribusi terbesar sampai terkecil adalah angin $\left(Y_{1}\right), \operatorname{SPL}\left(Y_{2}\right)$, tekanan udara di atas permukaan laut $\left(Y_{4}\right)$, dan $\operatorname{ASPL}\left(Y_{3}\right)$. Vektor loading kanonik menunjukkan korelasi antara variabel asal dengan variabel kanonik pada Tabel 6.

Tabel 6 menunjukkan bahwa variabel asal untuk fitur global yang memiliki korelasi paling kuat dengan variabel pertama adalah angin global $\left(X_{1}\right)$ pada kajian wilayah I, II, III, dan IV dengan nilai korelasi masing-masing adalah 0,987 ; 0,969; 0,987; dan 0,865. Tabel 6 menunjukkan variabel asal untuk fitur lokal yang memiliki korelasi paling kuat dengan variabel kanonik pertama adalah angin lokal $\left(Y_{1}\right)$ pada kajian wilayah I, II, III, dan IV dengan nilai korelasi 0,974; 0,952; 0,979 ; dan 0,845. Uji kenormalan data menggunakan uji
Anderson-Darling untuk fitur iklim di wilayah Nino 3.4 dan lokal dengan hipotesis, $\mathrm{H}_{0}$ : sebaran data berdistribusi normal dan $\mathrm{H}_{1}$ : sebaran tidak berdistribusi normal.

Berdasarkan pengujian Anderson-Darling maka p-value untuk setiap variabel dapat disajikan pada Tabel 7. Hasil pengujian normalitas menunjukkan data perubahan iklim di kedua wilayah (global dan lokal) memenuhi asumsi kenormalan data pada $\alpha=0,01$.

Selanjutnya melalui Tabel 8 pengujian hipotesis, $\mathrm{H}_{0}: \tau_{11}=\tau_{21}=\tau_{31}=\tau_{41}=0$ dan $\tau_{12}=\tau_{22}=\tau_{32}=\tau_{42}=0$, $\mathrm{H}_{1}$ : paling sedikit ada satu $\tau_{g p} \neq 0$, untuk $g=1,2,3,4 ; p=$ 1,2 (paling sedikit ada satu fitur iklim yang mempengaruhi perubahan iklim).

Berdasarkan Tabel 9 untuk $\alpha=0.05$ diperoleh $\chi_{p(g-1)}^{2}(0.05)=\chi_{6}^{2}(0.05)=12.59$. Untuk fitur iklim global (wilayah Nino 3.4) dan fitur iklim lokal (wilayah I, II, III, IV) dibandingkan dengan $\chi_{6}^{2}(0.05)=12.59$ maka diperoleh:

$-\left(n-1-\frac{(p+g)}{2}\right) \ln \Lambda^{*}>\chi_{6}^{2}(0.05)$.

Kesimpulannya menolak $\mathrm{H}_{0}$. Berdasarkan nilai pengaruh hubungan fitur untuk wilayah Nino 3.4 dan untuk wilayah lokal menunjukkan bahwa fitur iklim (angin, SPL, ASPL, dan tekanan udara di atas permukaan laut) mempengaruhi fitur iklim global sebesar 99,5\% dan

Tabel 4 Bobot kanonik variabel independen (perubahan iklim global)

\begin{tabular}{crrrr}
\hline \multirow{2}{*}{ Variat kanonik independen } & \multicolumn{3}{c}{ Fungsi ke-1 } \\
\cline { 2 - 5 } & Wilayah I & \multicolumn{2}{c}{ Wilayah II } & \multicolumn{2}{c}{ Wilayah III } \\
\hline Kovariat & Nino 3.4 & Nino 3.4 & Nino 3.4 \\
\hline$X_{1}$ & 0,968 & 0,940 & 0,970 \\
$X_{2}$ & 0,342 & 0,530 & 0,335 \\
$X_{3}$ & $-0,294$ & $-0,436$ & $-0,290$ \\
$X_{4}$ & $-0,004$ & 0,017 & $-0,015$ \\
\hline
\end{tabular}

Tabel 5 Bobot kanonik variabel dependen (fitur iklim lokal)

\begin{tabular}{crrrr}
\hline Variat kanonik dependen & \multicolumn{2}{c}{ Fungsi ke-1 } \\
\hline Variabel & Wilayah I & Wilayah II & \multicolumn{2}{c}{ Wilayah III } \\
\hline$Y_{1}$ & 0,960 & 0,932 & 0,967 \\
$Y_{2}$ & 0,246 & 0,335 & 0,223 \\
$Y_{3}$ & $-0,055$ & $-0,094$ & $-0,053$ \\
$Y_{4}$ & $-0,004$ & 0,014 & 0,505 \\
$0,0,203$ & 0,048 \\
\hline
\end{tabular}

Tabel 6 Loading kanonik variabel independen (fitur global (X) dan fitur lokal (Y))

\begin{tabular}{|c|c|c|c|c|}
\hline \multirow{2}{*}{ Variat kanonik independen } & \multicolumn{4}{|c|}{ Fungsi ke-1 } \\
\hline & Wilayah I & Wilayah II & Wilayah III & Wilayah IV \\
\hline Kovariat & Nino 3.4 & Nino 3.4 & Nino 3.4 & Nino 3.4 \\
\hline$X_{1}$ & 0,987 & 0,969 & 0,987 & 0,865 \\
\hline$X_{2}$ & 0,037 & 0,094 & 0,037 & 0,244 \\
\hline$X_{3}$ & $-0,108$ & $-0,088$ & $-0,106$ & $-0,045$ \\
\hline$X_{4}$ & 0,083 & 0,088 & 0,074 & 0,060 \\
\hline Variat kanonik dependen & & Fungsi k & & \\
\hline Variabel & Wilayah I & Wilayah II & Wilayah III & Wilayah IV \\
\hline$Y_{1}$ & 0,974 & 0,952 & 0,979 & 0,845 \\
\hline$Y_{2}$ & 0,242 & 0,318 & 0,221 & 0,527 \\
\hline$Y_{3}$ & $-0,086$ & $-0,076$ & $-0,089$ & $-0,060$ \\
\hline$Y_{4}$ & $-0,070$ & $-0,050$ & $-0,071$ & $-0,006$ \\
\hline
\end{tabular}


Tabel 7 Pengujian Normalitas Anderson-Darling (data perubahan iklim global dan lokal)

\begin{tabular}{|c|c|c|c|c|}
\hline Wilayah & Variabel & $P$-Value & $\alpha$ & Kesimpulan \\
\hline \multirow{8}{*}{ Nino 3.4} & \multirow{2}{*}{ Angin } & 0,172 & 0,05 & Terima $\mathrm{H}_{0}$ \\
\hline & & & 0,01 & Terima $\mathrm{H}_{0}$ \\
\hline & \multirow{2}{*}{ Suhu Permukaan Laut } & 0,023 & 0,05 & Tolak $\mathrm{H}_{0}$ \\
\hline & & & 0,01 & Terima $\mathrm{H}_{0}$ \\
\hline & \multirow{2}{*}{ Anomali Suhu Permukaan Laut } & 0,066 & 0,05 & Terima $\mathrm{H}_{0}$ \\
\hline & & & 0,01 & Terima $\mathrm{H}_{0}$ \\
\hline & \multirow{2}{*}{ Tekanan Udara di Atas Permukaan Laut } & 0,757 & 0,05 & Terima $\mathrm{H}_{0}$ \\
\hline & & & 0,01 & Terima $\mathrm{H}_{0}$ \\
\hline \multirow{8}{*}{ I } & \multirow{2}{*}{ Angin } & 0,895 & 0,05 & Terima $\mathrm{H}_{0}$ \\
\hline & & & 0,01 & Terima $\mathrm{H}_{0}$ \\
\hline & \multirow{2}{*}{ Suhu Permukaan Laut } & 0,435 & 0,05 & Terima $\mathrm{H}_{0}$ \\
\hline & & & 0,01 & Terima $\mathrm{H}_{0}$ \\
\hline & \multirow{2}{*}{ Anomali Suhu Permukaan Laut } & 0,070 & 0,05 & Terima $\mathrm{H}_{0}$ \\
\hline & & & 0,01 & Terima $\mathrm{H}_{0}$ \\
\hline & \multirow{2}{*}{ Tekanan Udara di Atas Permukaan Laut } & 0,044 & 0,05 & Tolak $\mathrm{H}_{0}$ \\
\hline & & & 0,01 & Terima $\mathrm{H}_{0}$ \\
\hline \multirow{8}{*}{ II } & \multirow{2}{*}{ Angin } & 0,760 & 0,05 & Terima $\mathrm{H}_{0}$ \\
\hline & & & 0,01 & Terima $\mathrm{H}_{0}$ \\
\hline & \multirow{2}{*}{ Suhu Permukaan Laut } & 0,305 & 0,05 & Terima $\mathrm{H}_{0}$ \\
\hline & & & 0,01 & Terima $\mathrm{H}_{0}$ \\
\hline & \multirow{2}{*}{ Anomali Suhu Permukaan Laut } & 0,070 & 0,05 & Terima $\mathrm{H}_{0}$ \\
\hline & & & 0,01 & Terima $\mathrm{H}_{0}$ \\
\hline & \multirow{2}{*}{ Tekanan Udara di Atas Permukaan Laut } & 0,306 & 0,05 & Terima $\mathrm{H}_{0}$ \\
\hline & & & 0,01 & Terima $\mathrm{H}_{0}$ \\
\hline
\end{tabular}

Tabel 8 Nilai lambda Wilks pada pengujian multivariat perubahan iklim global dan lokal

\begin{tabular}{cccc}
\hline & & \multicolumn{2}{c}{ Nilai lambda Wilks' } \\
\cline { 2 - 4 } Pengaruh & \multicolumn{2}{c}{ Wilayah Nino 3.4 } \\
\cline { 2 - 4 } & Wilayah I & Wilayah II & Wilayah III \\
\hline Fitur iklim & 0,002 & 0,002 & 0,003 \\
\hline
\end{tabular}

Tabel 9 Pengujian multivariat untuk masing-masing wilayah kajian

\begin{tabular}{llll}
\hline & & \multicolumn{2}{c}{ Iklim Lokal } \\
\hline Iklim Global & Wilayah I & Wilayah II & Wilayah III \\
\hline Wilayah Nino 3.4 & 273,46 & 273,46 & Wilayah IV \\
\hline
\end{tabular}

mempengaruhi fitur iklim lokal (masing-masing sebesar 99,8; 99,7; 99,6 dan 99,5\%.

\section{SIMPULAN}

Kajian korelasi terhadap fitur iklim selama periode 19512007 (56 tahun) dalam kaitan fitur ENSO menunjukkan terdapat korelasi antara variasi fitur iklim global (Nino 3.4) dan lokal (Provinsi Aceh untuk wilayah kajian) masingmasing 0,893; 0,899; 0,900; dan 0,901. Dari hasil analisis $C C A$, loading kanonik menunjukkan bahwa variabel asal memiliki korelasi kuat dengan variabel kanonik pertama adalah angin global $\left(X_{1}\right)$ dengan korelasi masing-masing wilayah 0,987 ; 0,$969 ; 0,987 ; 0,865$; dan angin lokal $\left(Y_{1}\right)$ dengan nilai korelasi masing-masing wilayah 0,$974 ; 0,952 ; 0,979 ; 0,845$. Sedangkan fitur iklim (SPL, ASPL, dan tekanan udara di atas permukaan laut) memiliki korelasi yang rendah dengan variabel kanonik pertama. Pengujian statistik melalui MANOVA menyimpulkan bahwa fitur iklim (angin, SPL, ASPL, dan tekanan udara di atas permukaan laut) mempengaruhi perubahan fitur iklim global dan lokal. Nilai $\eta^{2}$ menunjukkan ukuran hubungan pengaruh fitur iklim global (Nino 3.4) sebesar 99,5\% terhadap fitur iklim lokal masing-masing 99,8; 99,7; 99,6; dan 99,5\%. Kajian lebih mendalam diperlukan terhadap model probabilistik korelasi antar variasi fitur iklim, dengan menambah fitur iklim (faktor internal dan eksternal lainnya) selain memasukkan fitur pengaruh faktor lokal dan global serta multi interaksinya. Selain itu memasukkan variabel jarak antar ruang.

\section{UCAPAN TERIMA KASIH}

Ucapan terima kasih kepada DP2M Dikti yang telah mendanai salah satu bagian dari penelitian ini dalam Penelitian Hibah Bersaing tahun 2008 (No. 001/SP2H/PP/ DP2M/III/2008). Kami sampaikan pula terima kasih pada Lembaga Penelitian Unsyiah, Dekan FMIPA Unsyiah, Ketua Jurusan Matematika, Jurusan Ilmu Kelautan Unsyiah, BMKG, NOAA, dan semua pihak yang telah berpartisipasi dalam riset dan mempublikasikan hasil riset ini pada Jurnal Natur UNRI. 


\section{DAFTAR PUSTAKA}

Anderson, T.W. 1958. An Introduction to Multivariate Statistical Analysis. New York: John Wiley \& Sons.

Bannu. 2003. Analisis interaksi monsun, ENSO, dan dipole mode serta kaitannya dengan variabilitas curah hujan dan angin permukaan di benua maritim indonesia. Tesis, Institut Teknologi Bandung.

Bartlett, M.S. 1951. The goodness of Fit of A Single Hypothetical Discriminant Function in The Case of Several Groups. Ann. Eugen. Land. 16: 199-214.

Branston, A.G \& Ropelewski, C.F. 1992. Prediction of ENSO episodes using canonical correlation analysis. $J$. Climate 5: 1316-1345.

Chen, C.C., McCarl, B.A \& Adams R.M. 2000. Economic Implication of Potential ENSO Frequency and Strength Shifts. National Assessment of Climate Change, USA: Agriculture Focus Group.

Dillon, William R. \& Matthew, G. 1984. Multivariate Analysis Methods and Applications. New York: John Wiley \& Sons Inc.

Everitt \& Brian. 2005. An $R$ and S Plus Companion to Multivariate Analysis. London: Springer.

Everitt, Brian \& Hothorn, Torsten. 2011. An Introduction to Applied Multivariate Analysis with R. Springer.

Gaspersz \& Vincent. 1992. Teknik Analisis dalam Penelitian Percobaan. Bandung: Tarsito.

Hair, Joseph. F.J.R., Anderson., Rolh, E., Tatham., Ronald, L., Black \& William, C. 1998, Multivariate Data Analysis $5^{\text {th }} \mathrm{ed}$. New Jersey: Prentice Hall Inc.

Hardle, W.K \& Simar, L. 2012. Applied Multivariate Statistical Analysis. Manchester: Springer Verlag.

Hardon, D.R., Szedmak, S. \& Taylor, J.S. 2003. Canonical Correlation Analysis; An overview with application to learning methods. Technical Report. CSD-TR-03-02. Royal Holloway University of London.

Harijono \& Sri Woro, B. 2008. Analisis dinamika atmosfer di bagian utara ekuator sumatera pada saat peristiwa elNino dan dipole mode positif terjadi bersamaan. Jurnal Sains Dirgantara 5(2): 130-148.
Miftahuddin, et al.

Johnson, Richard, A \& Wichern., Dean, W. 2007. Applied Multivariate Statistical Analysis $6^{\text {th }}$ ed. New York: Prentice-Hall Inc.

Landman, W.A \& Mason, S.J. 1999. Operational long-lead prediction of south african rainfall using canonical correlation analysis. Royal meteorological society. International Journal of Climatology 19(10): 1073 1090.

Mardia, K.V., Kent, J.T \& Bibby, J.M. 1979. Multivariate Analysis. California: Academic Press.

Raykov, T \& Marcoulides, G.A. 2008. An Introduction to Applied Multivariate Analysis. New York, NY: Routledge. Read.

Rencher \& Alvin, C. 2002. Methods of Multivariate Analysis. Second Edition. Wiley Interscience: Brigham Young University.

Stevans \& James, P. 2009. Applied Multivariate Statistic for the Social Sciences. University of Cincinnati. Routledge: $5^{\text {th }}$ ed.

Supranto. 2004. Analisis Multivariant: Arti dan Interpretasi. Jakarta: Rineka Cipta.

Timm \& Neil, H. 2002. Applied Multivariate Analysis. New York, Inc: Springer Verlag.

Tjasyono, H.K \& Bayong. 1999. Klimatologi Umum. Bandung: ITB.

Trenberth, K.E., Fasullo, J.T \& Kiehl, J. 2009. Earth's global energy budget. Bull. Am. Meteorol. Soc. 90(3): 311323.

Wang, C., et al. 2012. El Nino and Southern Oscillation (ENSO): A Review. A chapter for Springer book: Coral Reefs of the Eastern Pacific. USA.

Wiratmo \& Joko. 1998. Sudah Benarkah Pemahaman Anda Tentang La Nina dan El Nino?. Bandung: ITB.

Yeh, S.W \& Kirtman, B.P. 2007. ENSO amplitude changes due to climate change projections in different coupled models. J. Climate 20: 203-217. 